\title{
Upaya pemeliharaan koleksi pustaka di Perpustakaan SMPN 57 PALEMBANG
}

\author{
Dewi Ratnasari, Vivin Oktaviani, Nurul Choirunnisa, Dandy \\ Julio Pratama, Imelda Putri Damayanti
}

\begin{abstract}
Maintenance of library materials is not new to the library. This is the task of the library manager, the establishment of a library means that library materials need to be maintained and preserved for the next generation. However, the task of preservation is not easy, because library managers will be faced with 'book enemies', namely: nerds, termites, cockroaches, mice, fungi and also by humans themselves such as tearing pages, folding paper, crossing pages, etc. other. This study aims to determine how to maintain library collections so that they are durable and what factors can damage library materials, as well as the obstacles faced by librarians in the process of maintaining library collections. From the results of the study the authors found that the library collection in the library of Palembang 57 Public High School was still not maximally processed due to lack of human resources and funds in the maintenance and repair of library materials in this library. For more details the author will explain the clarity in this paper. This research was conducted by means of collecting data quantitatively, then presented descriptively in analysis.
\end{abstract}

Keywords: Maintenance, Library, Constraints.

\section{Pendahuluan}

Perpustakaan merupakan sistem informasi yang didalamnya terdapat aktivitas, pengolahan, pengumpulan, pengawetan, pelestarian dan penyajian serta penyebaran informasi. Perpustakaan sebagaimana yang ada dan berkembang sekarang telah digunakan sebagai salah satu pusat informasi, sumber ilmu pengetahuan, penelitian, rekreasi, pelestarian khasanah budaya 
bangsa, serta memberikan berbagai layanan jasa lainnya (Lasa Hs, 1998). Menurut Sutarno, perpustakaan adalah mencakup suatu ruangan, bagian dari gedung/bangunan atau gedung tersendiri yang berisi buku-buku koleksi, yang diatur dan disusun demikian rupa, sehingga mudah untuk dicari dan dipergunakan apabila sewaktu-waktu diperlukan oleh pembaca (Sutarno, 2006). Perpustakaan yang baik adalah perpustakaan yang selalu menjaga dan memelihara bahan pustaka dari kerusakan, agar bahan pustaka bisa digunakan untuk kebutuhan pengguna bahan pustaka.

Pemeliharaan yang kata dasarnya "pelihara" yang ditambah awalan pe dan akhiran an yang berarti menjaga agar tidak cepat rusak dan tahan lama. Dalam Kamus Bahasa Indonesia, pemeliharaan berarti merawat atau menjaga sesuatu agar dapat terpelihara dengan baik. Menurut Soetminah (1992:126) pemeliharaan bahan pustaka merupakan kegiatan menjaga atau mengasuh agar bahan pustaka yang dimiliki tetap awet dan terawat dengan baik (Soetimah, 2002).

Pemeliharaan bahan pustaka adalah upaya untuk menjaga keselamatan buk-buku dan bahan lain dari kerusakan sehingga bahan pustaka tersebut dapat dimanfaatkan dalam waktu yang lama. Dalam pengertian pemeliharaan termasuk perawatan dan pencegahan dari kerusakan sehingga bahan pustaka itu dapat dilestarikan.

Pemeliharaan bahan pustaka merupakan kegiatan yang mencakup segala usaha pencegahan terhadap hal-hal yang menimbulkan kerusakan buku atau dengan kata lain 
menyelamatkan buku dari unsur-unsur yang rusak. Secara umum, usaha pemeliharaan bahan pustaka ialah dengan menjaga kebersihan ruangan perpustakaan itu sendiri, seperti lemari, rak, dan buku bebas dari debu. Mengadakan larangan merokok, makan dan minum dalam ruang perpustakaan (Martoadmojo, 1993).

Pemeliharaan bahan pustaka dilakukan untuk menjaga kandungan bahan pustaka. Pada dasarnya, pemeliharaan bahan pustaka itu bisa dilakukan dengan merawat bentuk aslinya. Apabila pemeliharaan dilakukan dengan baik dan terus menerus, maka semua koleksi akan terlindungi.

Dapat disimpulkan dari pernyataan diatas bahwa pemeliharaan merupakan cara untuk menyimpan informasi yang ada di dalam bahan pustaka dalam bentuk aslinya dan bahan pustaka itu sendiri dalam jangka waktu lebih lama.

Pemeliharaan bahan pustaka merupakan suatu usaha yang dilakukan oleh petugas perpustakaan dalam mencegah dan menyelamatkan koleksi bahan pustaka tetap awet dan terjaga kelestariannya. Pemeliharaan bahan pustaka tidak hanya secara fisik saja, namun juga meliputi isinya yang berbentuk informasi yang terkandung didalamnya (Martoadmojo, 1993).

Menurut Jyotshna Sahoo:

"Preservation is the process in which all actions are taken to check and retard deterioration."

Menurut pendapat diatas bisa ditarik kesimpulan bahwa pelestarian bahan pustaka adalah proses usaha untuk melakukan segala sesuatunya demi mencegah ataupun memperlambat 
kerusakan dari koleksi bahan pustaka baik secara fisik pustakanya ataupun informasi yang terkandung.

Secara umum upaya pemeliharaan bahan pustaka ialah dengan menjaga kebersihan ruangan perpustakaan itu sendiri, lemari, rak, dan buku bebas dari debu. Mengadakan larangan merokok, makan dan minum di dalam perpustakaan. Merokok selain menambah kotor dengan abu rokok yang bertaburan juga dapat menimbulkan kebakaran pada bahan buku. Sedangkan ceceran makan dan tumpahan minuman mengandung kehadiran tikus, serangga yang merupakan musuh-musuh bahan pustaka. Untuk mencegah hal tersebut umumnya telah dimasukkan dalam peraturan tata tertib perpustakaan (Razak M., 1992).

Pemeliharaan bahan pustaka bukanlah hal yang baru bagi perpustakaan. Hal ini menjadi tugas pengelola perpustakaan, berdirinya perpustakaan berarti adanya bahan pustaka yang perlu dipelihara dan dilestarikan untuk generasi selanjutnya. Namun, tugas pelestaran bukanlah hal yang mudah, karena pengelola perpustakaan akan berhadapan dengan 'musuh buku' yaitu: kutu buku, rayap, kecoak, tikus, jamur dan juga oleh manusia itu sendiri seperti merobek halaman, melipat kertas, mencoret halaman, dll.

\section{Menurut Kademani:}

"Causes of deterioration may be external or internal. External causes are physical, chemical, biological, improper storage, unauthorized exposure, risky handling, theft, natural calamities. Internal causes are: poor quality of paper or materials used, the chemicals used for printing and binding" (Kademani dkk., 2003). 
Yang mengatakan bahwa penyebab kerusakan bahan pustakabisa jadi eksternal atau internal. Penyebab eksternal adalah fisik, kimia, biologis, penyimpanan yang tidak benar, paparan yang tidak sah, penanganan yang berisiko, pencurian, bencana alam. Penyebab internal adalah: buruknya kualitas kertas atau bahan yang digunakan, bahan kimia yang digunakan untuk mencetak dan mengikat.

\section{Tujuan Pemeliharaan Bahan Pustaka}

Tujuan pemeliharaan bahan pustaka di perpustakaan adalah untuk menyelamatkan nilai-nilai informasi yang terkandung di dalam bahan pustaka atau dokumen. Mempercepat penelusuran dan perolehan informasi, menjaga keindahan dan kerapian bahan pustaka, mencegah koleksi perpustakaan dari kerusakan (Martoadmojo, 1993). Dengan adanya pemeliharaan yang baik, diharapkan bahan pustaka akan awet dan tidak cepat rusak. Jika pemeliharaan tidak dijalankan dalam perpustakaan maka akan terjadi kerusakan pada bahan pustaka dan anggaran perpustakaan akan terbebani.

\section{Fungsi Pemeliharaan Bahan Pustaka}
1) Fungsi perlindungan
2) Fungsi pemeliharaan
3) Fungsi kesehatan
4) Fungsi pendidikan
5) Fungsi sosial
6) Fungsi ekonomi
7) Fungsi keindahan

\section{Manfaat Pemeliharaan Bahan Pustaka}

Ada beberapa manfaat pemeliharaan bahan pustaka, yaitu: 
1. Memelihara bahan pustaka yang ada di perpustakaan.

2. Mengolah perlengkapan perpustakaan yang meliputi pengadaan, pemeliharaan, penyaluran, dan inventaris.

3. Melestarikan bahan pustaka dari hal-hal yang dapat merusak bahan pustaka.

4. Melindungi bahan pustaka dari penyebab kerusakan bahan pustaka tersebut agar tetap awet dan lestari.

5. Memperbaiki buku-buku yang tidak teratur pada tempatnya (Martoadmojo, 1993).

Pemeliharaan bahan pustaka tidak hanya secara fisik saja, namun juga meliputi isinya yang berbentuk informasi yang terkandung didalamnya. Pemeliharaan merupakan kegiatan mengusahakan agar bahan pustaka yang kita kerjakan tidak cepat mengalami kerusakan, awet, dan bisa dipakai lebih lama serta bisa menjangkau lebih banyak pembaca di perpustakaan (Moedzakir, 1980). Pemeliharaan bahan pustaka merupakan suatu kegiatan yang sangat penting, dimana dengan adanya pemeliharaan yang baik dan benar, diharapkan bahwa koleksi bisa bertahan lama. Dalam kegiatan perpustakaan, pengelolaan sering kali mengabaikan kegiatan pemeliharaan, sehingga bidang pemeliharaan masih kurang mendapat perhatian dari pengelolaan perpustakaan. Akibatnya koleksi yang ada di perpustakaan mengalami kerusakan dan bahkan sampai kepada koleksi tersebut tidak dapat digunakan lagi (Junaedi, 2006). 
Hal ini terjadi pada perpustakaan SMP Negeri 57 Palembang. Kerusakan bahan pustaka terjadi karena faktor-faktor lingkungan seperti cahaya, suhu, kelembaban dan udara juga mempercepat proses. Faktor lainnya adalah adanya rak buku yang sudah cukup diamakan usia karena sudah tidak layak pakai tetapi masih digunakan karena kekurangan rak baru untuk menampung bahan koleksi yang ada serta karena sekolah itu masih baru jadi ruangan perpustakaannya masih belum terorganisir dengan baik dan masih banyak buku-buku yang berserakan dapat mempercepat proses keruskan bahan pustaka. Beberapa permasalahan yang akan diteliti, diantaranya: Apa penyebab kerusakan koleksi pustaka di perpustakaan SMP Negeri 57 Palembang?Bagaimana proses pemeliharaan koleksi pustaka di perpustakaan SMP Negeri 57 Palembang? Kendala apa yang dihadapi petugas perpustakaan SMP Negeri 57 Palembang dalam proses pemeliharan bahan pustaka?

Tujuan umum dari penelitian ini adalah mengetahui bagaimana cara pemeliharaan koleksi pustaka agar tahan lama dan faktor apa saja yang dapat merusak bahan pustaka, serta kendala yang dihadapi oleh pustakawan dalam proses pemeliharaan koleksi pustaka.

\section{Metode Penelitian}

Penelitian ini merupakan penelitian kualitatif yang memerlukan data berupa kata-kata tertulis, data lisan, dan perilaku yang dapat diamati. Untuk mendapatkan hal itu, penulis meggunakan metode deskriptif. Metode deskriptif adalah metode 
penelitian yang memberikan gambaran atau uraian atas suatu keadaan sejelas mungkin tanpa ada perlakuan terhadap objek yang diteliti (Kuntoro, 2005). Karena itu metode penelitian yang digunakan studi kasus dengan menggunakan teknik wawancara dan observasi.

\section{Gambaran Lokasi Penelitian}

Perpustakaan sekolah adalah perpustakaan yang diselenggarakan di sekolah guna menunjang program belajar mengajar di lembaga pendidikan formal tingkat sekolah, baik sekolah dasar maupun sekolah menengah, baik sekolah umum maupun sekolah lanjutan. Diumpamakan juga bahwa perpustakaan sekolah adalah "jantungnya" pelaksanaan pendidikan di sekolah tersebut (Bafadal, 1992).

\section{a. Tujuan Perpustakaan Sekolah}

Tujuan perpustakaan sekolah tidak terlepas dari tujuan diselenggarakannya pendidikan sekolah secara keseluruhan, yaitu untuk memberikan bekal kemampuan dasar kepada peserta didik (siswa atau murid), serta mempersiapkan mereka untuk mengikuti pendidikan menengah (Bafadal, 1992).

b. Fungsi Perpustakaan Sekolah:

Perpustakaan sekolah mempunyai 4 fungsi umum yaitu:

1) Fungsi edukatif

2) Fungsi informative

3) Fungsi kreasi

4) Fungsi riset atau penelitian. 
SMP Negeri 57 Palembang adalah salah satu SMP negeri yang ada di Palembang lebih tepatnya di Talang Aman, Kemuning, Kota Palembang, Sumatera Selatan. SMPN 57 ini masih menyandang akreditasi B karena SMP ini baru berdiri pada tanggal 14 Agustus 2014 dengan dipimpin oleh seorang kepala sekolah yang bernama H. Muhammad Daud. Dulunya, gedung SMP 57 ini merupakan SD 189 tetapi di alih fungsikan menjadi SMP 57. Jadwal kegiatan mengajar di sekolah ini dibagi menjadi 2 fase yaitu pagi dan siang hari, dimana siswa kelas 9 dan 8 belajar di pagi hari dan siswa kelas 7 memiliki jadwal siang hari.

Perpustakaan SMP 57 ini berdiri sejak berdirinya SMP 57 ini sendiri, karena setiap sekolah di wajibkan memiliki perpustakaan di dalamnya. Perpustakaan ini diolah oleh seorang pustakawan yang bernama Ibu Titin dan dibantu dengan kedua stafnya yang lain, tetapi stafnya tersebut bukanlah ahli dibidang peprustakaan. Merekalah yang mengelola semua kolkesi perpustakaan yang ada di perpustakaan SMPN 57 Palembang.

\section{Pembahasan}

Pemeliharaan bahan pustaka merupakan suatu kegiatan yang sangat penting, dimana dengan adanya pemeliharaan yang baik dan benar, diharapkan bahwa koleksi bisa bertahan lama. Dalam kegiatan perpustakaan, pengelolaan sering kali mengabaikan kegiatan pemeliharaan, sehingga bidang pemeliharaan masih kurang mendapat perhatian dari pengelolaan perpustakaan. Akibatnya koleksi yang ada di perpustakaan mengalami kerusakan dan bahkan sampai kepada koleksi tersebut tidak dapat digunakan lagi (Junaedi, 2006). 


\section{A. Faktor penyebab kerusakan koleksi pustaka}

Di perpustakaan SMPN 57 Palembang ada beberapa faktor yang menyebabkan kerusakan pada koleksi pustaka diantaranya sebagai berikut:

a. Faktor manusia

Tidak dapat dipungkiri bahwa pada umumnya manusia sebagai perusak utama terhadap bahan pustaka karena koleksi pustaka yang berada di perpustakaan diperuntukan untuk dibaca oleh manusia. Terkhususnya di perpustakaan SMPN 57 Palembang yang diperuntukan untuk siswa SMP. Kerusakan yang terjadi antara lain:

1) Semakin sering koleksi pustaka dipinjam oleh siswa, semakin tinggi tingkat kerusakan

2) Sebagian siswa kadang merobek bagian halaman tertentu sehingga halaman yang ada di buku tersebut ada yang hilang

3) Siswa kadang mencoret buku yang dibaca

4) Siswa juga kadang melipat halaman buku sebagai petunjuk halaman terakhir yang di baca, hal ini mempercepat kerusakan bahan pustaka

Untuk mengatasi masalah tersebut, para pustakawan di sekolah SMPN 57 Palembang melakukan usaha pencegahan, yaitu:

1) Memberikan pengertian pada siswa tentang arti dan pentingnya sebuah buku dan memperlakukan buku dengan baik

2) Melarang siswa makan dan minum di dalam perpustakaan karena ditakutkan akan mengotori buku-buku yang sedang dibaca dan sisa makanan akan mengundang tikus

3) Menata ruang baca dan koleksi pustaka seefisien mungkin agar memudahkan pengguna saat mencarai informasi

b. Faktor Biologi 
Kerusakan koleksi pustaka yang disebabkan oleh gangguan serangga seperti rayap, tikus, kecoa, dan lain-lain. Untuk mencegahnya pustakawan di perpustakaan SMPN 57 Palembang melakukan pencegahan dengan membersihkan lingkungan tempat koleksi agar tidak ada hewan perusak koleksi bersarang didalamnya.

Dapat disimpulkan bahwa perpustakaan SMPN 57 Palembang sering mengalami kerusakan bahan pustaka dikarenakan faktor manusia dan faktor biologi. Menurut analisis penulis, faktor yang paling utama adalah manusia itu sendiri, seringkali siswa/siswi SMPN 57 Palembang mencoret ataupun merobek buku. Dan untuk faktor biologi, bu Titin selaku tenaga pengelola perpustakaan ini menaruh kapur barus sebagai upaya pencegahan kerusakan bahan pustaka akibat serangga ataupun hewan perekat seperti tikus.

\section{B. Upaya pemeliharaan}

sebagai sarana penyedia layanan informasi, perpustakaan perlu meningkatkan dan mengembangkan layanan perpustakaan.hal ini tidak dapat dicapai dengan baik tanpa menjaga dan mempertahankan kondisi fisik bahan pustaka. Melalui kegiatan pemeliharaan ini, pengembangan dapat dilaksanakan dengan baik dan memuaskan. Perpustakaan SMPN 57 Palembang, dalam melaksanakan pemeliharaan bahan pustaka masih menggunakan cara manual. Upaya yang harus ditempuh petugas perpustakaan dalam kegiatan pemeliharaan bahan pustaka, yaitu sebagai berikut:

1. Membersihkan buku dari debu 
Membersihkan buku dari debu merupakan kegiatan rutinitas pertugas perpustakaankarena sebagai salah satu persyaratan dalam pelestarian bahan pustaka agar tetap terjaga. Buku harus sering di bersihkan agar tidak berdebu.

2. Memperbaiki kerusakan buku

Pada dasarnya kerusakan buku ada dua macam, yaitu kerusakan kecil, seperti buku terkena air, halaman sobek sebagian atau halamanya terlepas, sedangkan kerusakan besar seperti halamanya buku yang hilang, sebagian halaman buku yang terbakar sehingga buku tersebut tidak dapat digunakan lagi. Untuk kerusakan kecil perlu segera di perbaiki oleh petugas perpustakan. Sedangkan untuk kerusakan besar apabila tidak bisa diperbaiki lagi perlu disiangi (dihapuskan dari koleksi perpustakaan).

Di perpustakaan SMPN 57 Palembang melakukan cara memperbaiki buku yang rusak dengan di lem atau diisolasi yang robek dan bila banyak yang lepas, bisa dijilid dan disampul ulang.

3. Mengatur buku pada rak

Pada perpustakaan SMPN 57 Palembang sebenarnya sudah menyusun buku dengan baik, seperti: mengisi buku pada rak hanya $80 \%$ dengan menggunakan pembatas buku pada rak dan memberikan kapur barus pada rak agar terhindar dari serangga perusak buku. Tetapi, dalam penyusunannya tidak berdasarkan nomor klasifikasi buku tetapi menggunakan label warna. Lebel warna yang digunakan masih berdasarkan nomor klasifikasi buku dan setiap warna mewakili setiap nomor klasifikasi. Tujuan dilakukannya 
pelebelan itu untuk memudahkan siswa dalam mencari buku yang diinginkan.

Kegiatan pemeliharaan fisik buku tidak hanya bertitik pada pemberian sampul saja, akan tetapi diperlukan usaha lain seperti pejilidan atau upaya untuk mengkokoh fisik buku. Buku berasal dari kertas karena itu tanpa disadari buku lama kelamaan akan using karena kelembaban, sobek, kusam, dan banyak lagi kerusakan-kerusakan yang disebabkan oleh hal-hal yang lain. Untuk itulah diperlukan usaha-usaha khusus seperti melekatkan halaman buku yang robek, mengganti sampul yang lembab dan keras sebagai usaha lainnya.

Berdasarkan hasil observasi, penulis pendapatkan data bahwa petugas perpustakaan melaksanakan upaya pemeliharaan bahan pustaka dengan cara membersihkan buku dari debu, memperbaiki kerusakan bulu dengan cara memberi lem pada buku yang rusak, menyampul buku dan menjilid buku. Dan penulis melihat sendiri bahwa bahan koleksi perpustakaan di perpustakaan SMPN 57 ini memang sudah di susun dengan baik tapi koleksi perpustakaan ini belum disusun berdasarkan nomor panggil (call number) dikarenakan siswa akan lebih mengerti jika menggunakan warna daripada menggunakan angka atau huruf.

\section{Kendala dalam Pemeliharaan}

Dalam upaya pemeliharaan bahan pustaka, perpustakaan SMPN 57 Palembang menghadapi beberapa kendala yang menyebabkan pelaksanaa pemeliharaan bahan pustakantidak 
terlaksana. Ada pun kendala-kendala yang dihadapi sebagai berikut:

1. Sumber Daya Manusia (petugas)

Perpustakaan SMPN 57 Palembang mengalami kendala pada tenaga khusus untuk mengolah perpustakaan, maka kegiatan pemeliharaan ini terhambat dan tidak terlaksana dengan sempurna. Pada perpustakaan ini seharusnya ada karyawan yang lulusan prodi ilmu perpustakaan.

2. Dana

Dana merupakan salah satu faktor yang sangat penting dalam semua bidang, apalagi bidang perpustakan. Pada SMPN 57 Palembang dana yan dialokasikan untuk mengelola khususnya pada saat melakukan perbaikan koleksi pustaka masih kurang, hanya untuk melakukan pelestarian sederhana yang dananya cukup untuk membeli peralatan yang dibutuhkan. Tetapi, jika untuk melakukan teknik pelestarian dengan bahaan kimia dan lainnya dana yang ada belum cukup untuk membeli alat yang dibutuhkan.

Dari uraian tentang kendala dalam pemeliharaan yang telah dijelaskan diatas dapat disimpulkan bahwa kendala kerusakan bahan pustaka di perpustakaan ini adalah SDM dan dana. Dari hasil wawancara bersama Ibu Titin selaku petugas perpustakaan SMPN 57 Palembang, ia menjelaskan bahwa yang mengelola perpustakaan ini hanya dirinya dan kedua staf nya dan ia beserta staf nya merupakan guru di SMP ini sehingga kurangnya waktu dalam pengawasan perpustakaan dan perbaikan bahan pustaka. Dan ia juga menjelaskan bahwa kurangnya dana dalam perbaikan 
bahan pustaka menjadi kendala dalam perbaikan bahan pustaka di pepustakaan ini. Dana yang di dapat juga masih belum bisa memenuhi kebutuhan perpustakaan ini, dapat dilihat dari ruangan perpustakaan ini sendiri masih di gabung dengan ruangan UKS sehingga perpustakaan ini terasa sangat sempit bahkan untuk sekedar membaca di perpustakaan ini pun terasa sangat tidak nyaman.

\section{Kesimpulan}

Berdasarkan hasil pembahasan sebelumnya, maka penulis dapat menarik kesimpulan bahwa:

1. Pemeliharaan bahan pustaka adalah kegiatan menjaga keselamatan buku-buku dan bahan koleksi lainnya dari kerusakan agar bahan pustaka yang dimiliki perpustakaan tetap awet dan terawat dengan baik.

2. Upaya pemeliharaan bahan pustaka pada perpustakaan SMPN 57 Palembang dilakukan dengan cara:

a. Cara yang tidak langsung

1) Ruang koleksi perpustakaan harus bebas dari debu.

2) Koleksi perpustakaan tidak boleh terkena sinar matahari secara langsung.

3) Sirkulasi udara harus berlangsung dengan baik, sehingga udara dalam ruangan tidak lembab.

4) Suhu udara dalam ruangan antara 18-20 celcius.

b. Cara langsung

1) Memperbaiki kerusakan buku

2) Menganti buku yang rusak

3) Merawat koleksi perpustakaan. 
c. Dana merupakan unsur yang sangat penting yang mempengaruhi kesuksesan setiap kegiatan, maka selaknya kepala sekolah dapat menempuh kebijaksanaan misalnya bekerjasama dengan pihak-pihak yang bisa menyalurkan dana untuk kelancaran aktifitas suatu perpustakaan, terutama dalam pemeliharaan bahan pustaka.

d. Hendaknya pada perpustakaan ada petugas yang memahami ilmu tentang perpustakaan atau orang yang sudah menempuh pendidikan pada prodi perpustakaan, agar lebih mudah dalam mengatasi masalah dalam perpustakaan.

e. Memberikan kesadaran bagi pemustaka dalam menggunakan koleksi baik itu meminjam maupun membaca diruang perpustakaan agar bisa menjaga koleksi dengan baik.

\section{Daftar Pustaka}

Bafadal, Ibrahim. 1992. Pengelolaan Perpustakaan Sekolah. Jakarta, Bumi Aksara.

Hs,Lasa.1998Kamus Istilah Perpustakaan. Yogyakarta. Gadjah Mada University Press.

Junaedi, M.J.2006.Pemeliharaan dan Pengawetan Bahan Pustaka.

Kademani, B. S. , V. L. Kalyane dan Vijai Kumar.2003.Preservation of Information Resources in Libraries: New Challenges. Bhabha Atomic Research Centre. Trombay.

Kuntoro, Roni.2005. Metode Penelitian. Jakarta. Ppm.

M.J, Junaedi.2006.Pemeliharaan dan Pengawetan Bahan Pustaka. Martoadmojo, Karmiri. 1993. Materi Pokok Pelestarian Bahan Pustaka.Jakarta, Universitas Terbuka.

Martoadmojo, Karmiri. 1993.Materi Pokok Pelestarian Bahan Pustaka.Jakarta. Universitas Terbuka. 


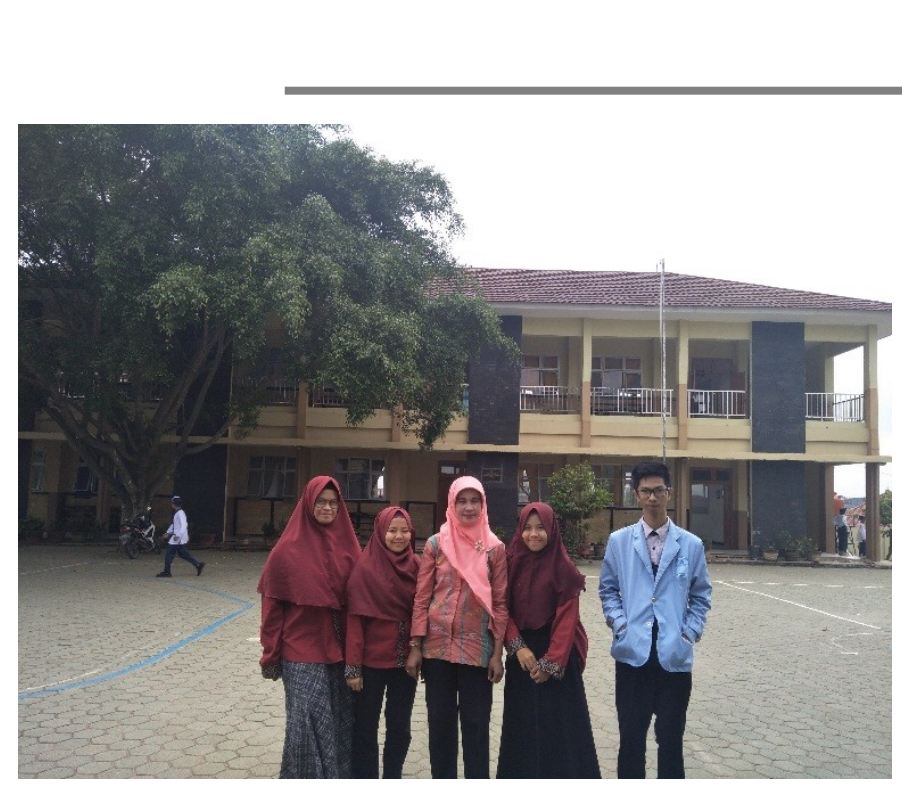

Jurnal Iqra' Volume 13 No.01 $\mid$ Mei 2019

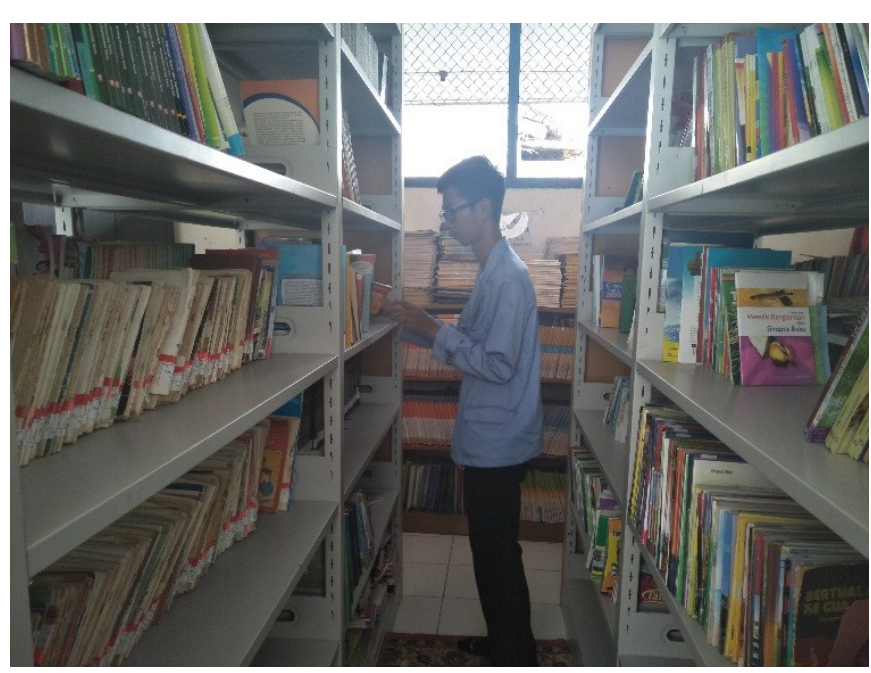

Moedzakir. 1980.Pemeliharaan Buku

dan Menjilid. Yogyakarta. Pusdiklat Perpustakaan IKPI.

NS, $\quad$ Sutarno. 2006, Perpustakaan dan Masyarakat, Jakarta. Sagung Seto.

Razak, M.1992.Pelestarian Bahan Pustaka dan Arsip. Jakarta. Gramedia Pustaka Utama.

Sahoo, Jyotshna.Preservation of Library Materials: Some Preventive

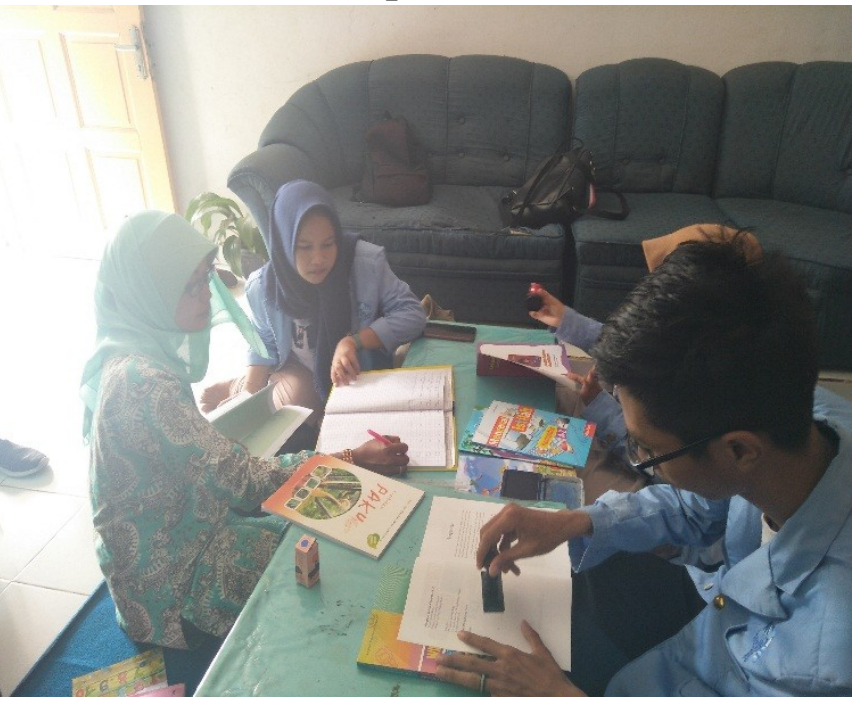

Measures, OHRJ, Vol. XLVII. No.1. 


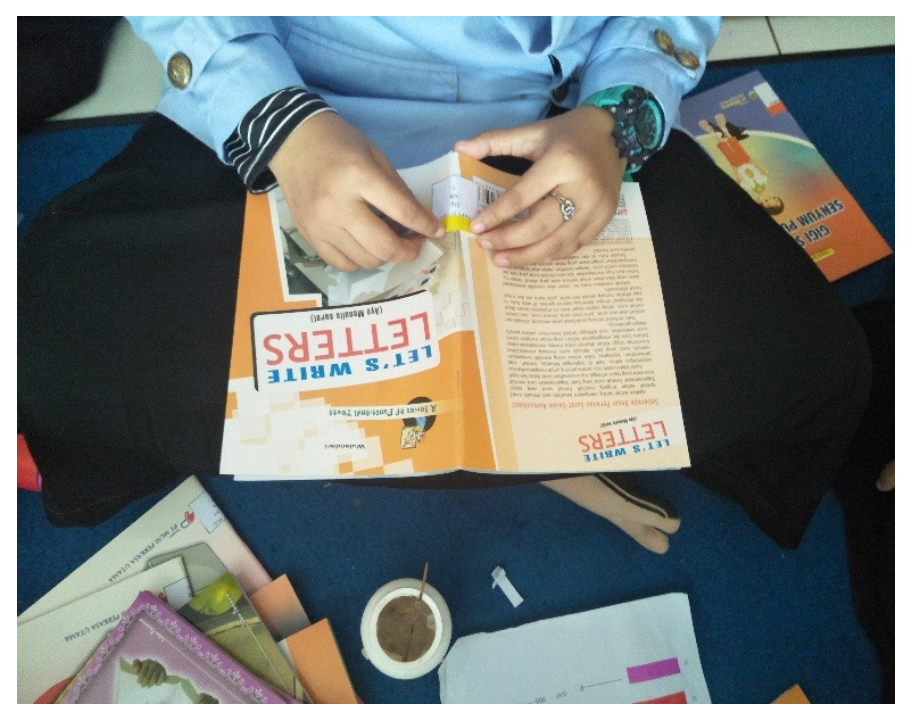

